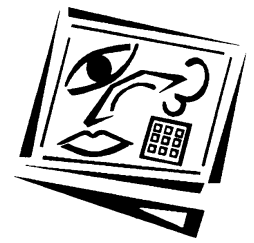

\title{
The e-portfolio continuum: Discovering variables for e-portfolio adoption within music education
}

\author{
John Taylor, Peter Dunbar-Hall and Jennifer Rowley \\ The University of Sydney

\begin{abstract}
This article presents the results of audit data compiled from a case study introducing e-portfolios into a Music Education degree program, and highlights the key challenges faced from the initial stages of student use to curricular embedding and student adoption. This article discusses the technological, social and educational impacts inherent in a student's adoption of e-portfolios within a degree program, and critically, shows how training for e-portfolio use must manage these complex,
\end{abstract} \\ interrelated imbalances on an individual student basis.
}

\section{Introduction}

Electronic portfolios (e-portfolios or ePortfolios) are increasingly becoming standard products for demonstrating the skills required for and acquired by students in university training, particularly in degree programs that lead to professional accreditation and placements. Their use has become a regular topic of research publication in pedagogic areas such as nursing and medicine (Garrett \& Jackson, 2006), teaching (Granberg, 2010), veterinary science (Widdowson, 2010), engineering (Botterill, White \& Steiner, 2010), midwifery (Stewart, 2010), the health industry (von Konsky \& Comfort, 2010), and computing (Marriott \& Chomba, 2010). Alongside discipline-specific applications such as these, research on e-portfolios also covers their use across university study as a gauge of acquisition of skills (Challis, 2005), a site of assessment (Barrett, 2001), an aid for adult learners (Jones, Barnes, Lindley, Steinberg, Upadhyay \& Wilkinson, 2010), a place where students learn (Akcil \& Arap, 2009), an impetus for learner self-reflection (Barrett \& Garrett, 2009), a tool for independent learning (Chau \& Cheng, 2010), a shared space for group interaction (Sutherland, Brotchie \& Chesney, 2011) and collaboration (Oliver \& Nikoletatos, 2009), a site for learning outside formal curricula (Oliver, von Konsky, Jones, Ferns \& Tucker, 2009), and a method for assessing graduate employability (Oliver, 2010).

A recurring issue that underpins much of this research is the relationship between students' assumed identities as experienced and astute users of information and social networking technologies, and their taking up of e-portfolios as both a component and outcome of their studies (e.g., Oliver \& Goerke, 2007; Darnton, 2011); at question is whether there is a beneficial link between students' uses of digital technologies in contexts outside their studies, and their uses of them as part of their studies (Gray, Thompson, Sheard, Clerehan \& Hamilton, 2010). In this debate students are often perceived and referred to as 'digital natives', with the implication that they are 'technoliterates' with 'inbuilt' information technology skills and acceptances (e.g. McAlpine, 2005; Hemmi, Bayne \& Land, 2009). 
The aim of this article is to investigate and analyse factors relating to ways in which students in a four-year music education degree program at an Australian university have shown their adoption of e-portfolios, as a part of their studies. This is one element of an on-going series of discussions of the introduction of e-portfolios into this degree program in which a range of topics have been covered. These are: e-portfolios as a means of demonstrating music education skills and professional requirements (Rowley \& Dunbar-Hall, 2009); problems of e-portfolio implementation into a music education degree program (Dunbar-Hall et al, 2010); e-portfolios and pedagogy (Rowley \& Dunbar-Hall, 2010); e-portfolios and mapping of the music education pre-service curriculum (Rowley \& Dunbar-Hall, 2011a); students' reactions to e-portfolios (Rowley \& Dunbar-Hall, 2011b); and relationships between e-portfolios and student learning (Rowley, 2010).

As part of this series of discussions, this article presents a final aspect of a three-year project to implement and evaluate e-portfolios into the preparation of music educators. The project (funded by the University of Sydney under a Teaching Improvement and Equipment Scheme (TIES) grant for the period 2009-2011) had multiple aims, reflecting the range of expectations of music education pre-service training. From students' perspectives, it needed to provide access to an e-portfolio template through which demonstration of generic skills of university study could be made; allow documentation of students' abilities to respond to official NSW State Government teacher accreditation requirements (see http:/ / www.nswteachers.nsw.edu.au/); give students a site through which they could show their music education multiple identities - as pedagogues, composers, performers, researchers, ensemble directors, community musicians, etc.; and demonstrate the ability to use current forms of information technology as an embedded part of their studies and subsequent teaching. From staff perspectives, the introduction of e-portfolios could be used to link the content of this degree program to NSW Institute of Teachers professional teacher accreditation rubrics, thus assisting in official registration of the degree program; become a medium for a range of assessment tasks; be adapted as a form of curriculum mapping and evaluation; and ensure that information technology could be continually integrated into this four-year degree program.

A number of issues relating to student uses of e-portfolios emerged as data was collected. These are discussed below in the following order: artefact typology; gender and year group differences in artefact creation; e-portfolio construction and artefact distribution; e-portfolio parameters; assessment tasks; training; student experience; technological friction; network partitioning; and, perception of high type artefact use.

\section{Method}

With these aims guiding the project, two methodological activities were undertaken: focus group interviews with students, and one-to-one instruction for students by a technology expert. Three focus group interviews were held over the period of the project. These were voluntary and moved from initial discussion of the possibilities of e-portfolios and their contents (in the first interview), to more evaluative comments from students as they worked on their e-portfolios (in the second interview), to summative comments from students about their e-portfolio experiences (in the third, and final, interview). From the early focus group interviews, it became clear that students needed technological training in constructing their e-portfolios. This was in response to a number of factors: students' differing levels of technological competence 
and confidence; the need to address specific pedagogic requirements within e-portfolios (such as production and uploading of audio and film materials prepared as assessment tasks in specific subject areas); and the decision by the University involved to mandate a commercial e-portfolio product, use of which required understanding of its unique navigation and uploading functions.

The project therefore provided one-to-one tuition by an expert, which was available on an optional, first come, first served basis. Due to the individual nature of the tuition, a diversity of e-portfolio related instruction and advice was given, including topics and problems ranging from basic navigation and form completion to preparatory video compression techniques for upload into e-portfolios. Throughout this instructional process students were audited to show the level of activity of artefact creation within e-portfolios as an indicator of technological proficiency and development, and as a gauge of technological adoption of e-portfolios within the degree program. The audits also sought, within these technological spheres, to distinguish gender and year group differences, and to draw correlations between embedded curricular assessment and organic adoption of e-portfolios.

In order for assessment tasks to be graded, students were required to submit their work to a centralised online portal containing four repositories (one for each year group/cohort in this degree program), where all students' work was accessible by eportfolio teaching staff (as administrators of the portal) and the relevant staff member; each student's work was visible only to themselves (as restricted users of the portal). The audits were carried out by an independent e-portfolio staff member, and consisted of logging into the online portal, manually looking at each artefact contained in each repository, and making a note of the following information: repository, the gender of the artefact creator, the type of artefact created, and the content of the artefacts (whether they contained embedded/linked artefacts, or non-standard graphics themes). All figures are based on items published by the student to the relevant repository. This may not include all of the items created, as students may not have published all of their artefacts. Similarly, students can remove items from the repository.

In total, three audits took place. The first on 28 July 2010 (semester 2) coincided with the beginning of formal e-portfolio training and the start of curricular embedding of eportfolios; in this audit, there were 28 second year students (13 male and 15 female), and 29 third year students ( 8 male, 21 female). The second audit took place on 29 November 2010 (at the end of semester 2) and was done to compare students' progress during the semester; there were no changes in student numbers between these two audits. The third audit took place on 19 July 2011 (semester 2), and coincided with the end of formal training sessions on e-portfolios; due to enrolment variations, there were 24 second year students in this audit compared to 28 in the previous audit, although the relative gender percentage split remained the same (11 male, 13 female). It is worth noting that due to the timing of the project, semester 1, 2011 saw the previous second year students become third year students, and the previous third year students become fourth year students. For consistency and clarity within this article, this will be ignored. A timeline of audit dates and key milestones within the degree program for the audit periods can be seen in Figure 1. 'Prac' is used to refer to Practice Teaching sessions which students are required to undertake at various stages throughout the degree program. 


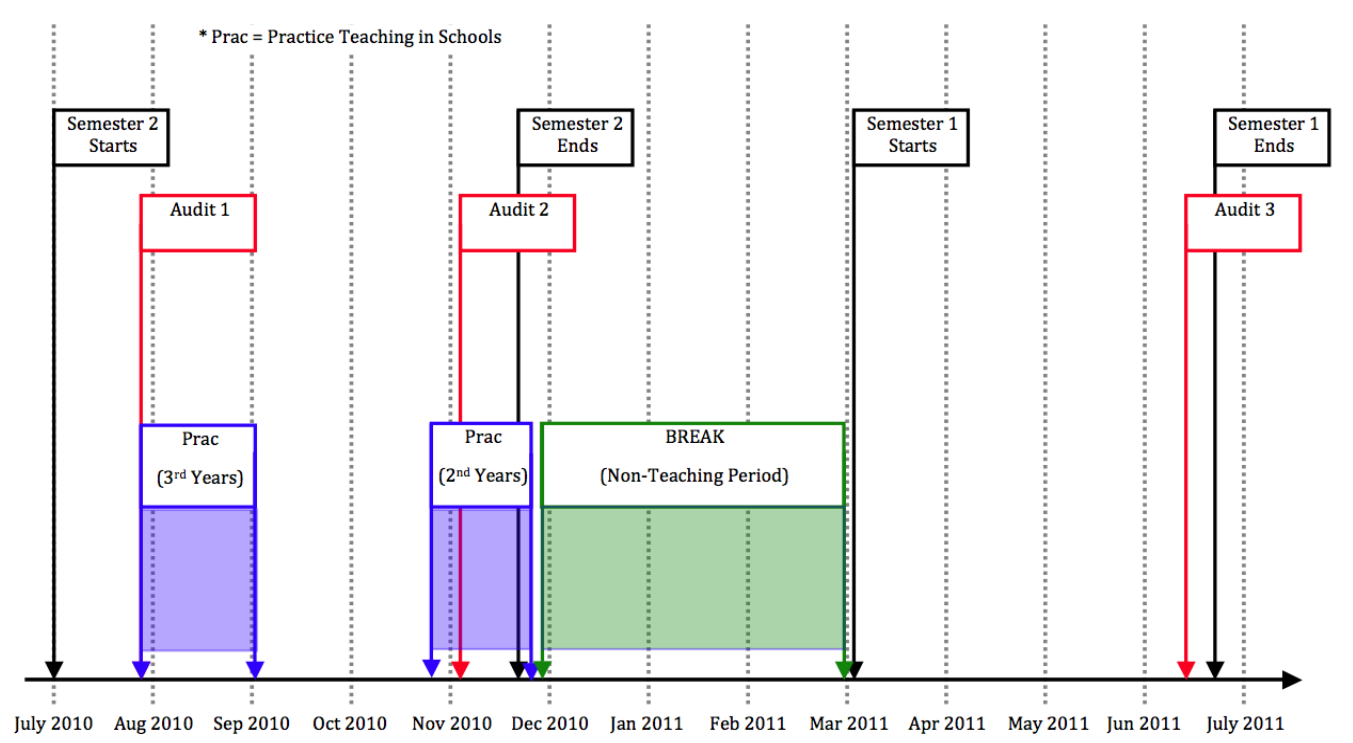

Figure 1: Timeline of key milestones and audit dates

Having presented the circumstances in which e-portfolios were introduced, and how students received training in their production, the next sections will focus on artefact typology, and presentation of the audit material, with particular reference to artefact creation for gender and year group, e-portfolio construction, and artefact distribution.

\section{Artefact typology}

To apply the audit data as measurement indices to technological proficiency and development, and, as a referent towards a unified measure of technological adoption of e-portfolios, it was necessary to analyse the types of artefacts available for creation, from simple online forms to complex video (often involving not only filming, but editing and encoding constraints), and with different levels and types of e-portfolio implementation and abstraction, it was necessary to distinguish and categorise different assets using a single, consistent framework. This 'e-portfolio component complexity framework' can be seen in Table 1.

The next section presents the findings of these audits in the context of the e-portfolio component complexity framework, together with discussion, which provide an insight into students' experiences of technological proficiency and development.

\section{Results}

Prior to the first Audit Point in July (Figure 1), there was no training given to students on the use of e-portfolios. At this stage of the implementation of e-portfolios, the concept had been discussed with students, the selected e-portfolio platform had been introduced, and the initial e-portfolio tasks had been embedded into a small number of subject areas. Showing the total number of artefacts created at the three Audit Points by year group, Figure 2 indicates that despite no formal training, both second and third year students had created artefacts as part of assessment tasks. With similar 
numbers of students, there were more artefacts created by third year students than second year students. The trajectory of both year groups in artefact creation between Audit Point 1 and 2 can be attributed to both sets of students taking part in Prac. With Practice Teaching an important aspect of music education training, it could be argued that e-portfolios took a lower level of priority for students at this time, as students needed time to focus on the expectations and experiences of Prac (such as lesson preparation and resource production) and other assessment tasks required by their studies.

Table 1: E-portfolio component complexity framework

\begin{tabular}{|c|c|c|c|c|c|}
\hline Rating & Definition & Format & Example & Requirements & Abstraction \\
\hline $\begin{array}{c}1 \\
\text { (easy) }\end{array}$ & $\begin{array}{l}\text { Fill in an } \\
\text { online form }\end{array}$ & Text input & 'About me' & $\begin{array}{l}\text { Log on, find form, } \\
\text { type and edit text, } \\
\text { save }\end{array}$ & $\begin{array}{l}\text { Factual } \\
\text { information. }\end{array}$ \\
\hline 2 & $\begin{array}{l}\text { Upload an } \\
\text { MS Office- } \\
\text { based } \\
\text { document }\end{array}$ & $\begin{array}{l}\text { Word document, } \\
\text { PDF, PowerPoint } \\
\text { presentation, } \\
\text { image file, Excel, } \\
\text { etc. }\end{array}$ & $\begin{array}{l}\text { Lesson plans, } \\
\text { teaching, Pract- } \\
\text { icum reports, CV, } \\
\text { assignments, } \\
\text { qualifications }\end{array}$ & $\begin{array}{l}\text { Create the } \\
\text { document and } \\
\text { upload it }\end{array}$ & $\begin{array}{l}\text { Context based. } \\
\text { Can be used as } \\
\text { evidence. }\end{array}$ \\
\hline 3 & $\begin{array}{l}\text { External } \\
\text { online } \\
\text { referencing }\end{array}$ & Hyperlink & $\begin{array}{l}\text { YouTube clip, } \\
\text { personal web } \\
\text { sites, affiliation } \\
\text { web sites, email } \\
\text { addresses }\end{array}$ & $\begin{array}{l}\text { Insert hyperlink } \\
\text { into text to } \\
\text { external web site }\end{array}$ & $\begin{array}{l}\text { Context based. } \\
\text { Can be used as } \\
\text { evidence. Shows } \\
\text { external online } \\
\text { awareness. }\end{array}$ \\
\hline 4 & $\begin{array}{l}\text { E-portfolio } \\
\text { CV } \\
\text { Blog }\end{array}$ & $\begin{array}{l}\text { 'Webfolio', } \\
\text { e-portfolio CV, } \\
\text { blog, bulletin } \\
\text { board }\end{array}$ & $\begin{array}{l}\text { Online CV, blog, } \\
\text { reflective journal } \\
\text { for practicum } \\
\text { teaching }\end{array}$ & $\begin{array}{l}\text { Merging different } \\
\text { asset types into a } \\
\text { sub-context, for } \\
\text { integration into } \\
\text { larger portfolio }\end{array}$ & $\begin{array}{l}\text { Shows manage- } \\
\text { ment of individ- } \\
\text { ual assets with a } \\
\text { subset of assets. } \\
\text { Compiled towar- } \\
\text { ds a common } \\
\text { global context. }\end{array}$ \\
\hline $\begin{array}{c}5 \\
\text { (diffi- } \\
\text { cult) }\end{array}$ & $\begin{array}{l}\text { Upload } \\
\text { video, } \\
\text { audio }\end{array}$ & $\begin{array}{l}. \text { wav } \\
. m p 3 \\
. m o v \\
. m p 4, \text { etc. }\end{array}$ & $\begin{array}{l}\text { Student perform- } \\
\text { ances, interviews, } \\
\text { sound recording } \\
\text { of music, inter- } \\
\text { views, short } \\
\text { documentary style } \\
\text { research, etc. }\end{array}$ & $\begin{array}{l}\text { Record an event } \\
\text { using technology } \\
\text { and hardware, } \\
\text { process into use- } \\
\text { able format, edit, } \\
\text { upload to } \\
\text { e-portfolio, } \\
\text { contextualise in } \\
\text { e-portfolio }\end{array}$ & $\begin{array}{l}\text { Shows manage- } \\
\text { ment of process } \\
\text { through the } \\
\text { capture of extern- } \\
\text { al digital artefacts } \\
\text { - collection, edit- } \\
\text { ing, contextual- } \\
\text { ising, compiling. }\end{array}$ \\
\hline
\end{tabular}

\section{General artefact creation}

This is in contrast to the significant increase in the number of artefacts created between Audit Points 2 and 3 . While this can also be attributed to the longer time between Audit Points, there was a three-month non-teaching period and no Practice Teaching in semester 1 for either year group. It is worth noting that due to the online nature of the e-portfolio platform, all students had access to their e-portfolio during Practice Teaching and non-teaching periods. Furthermore, e-portfolios became more integrated into the curriculum in semester 1, with more assessment tasks being related to eportfolio production. This could also account for the sharp increase in artefact numbers. Interestingly, the third years had created almost $40 \%$ more artefacts than the second years. 


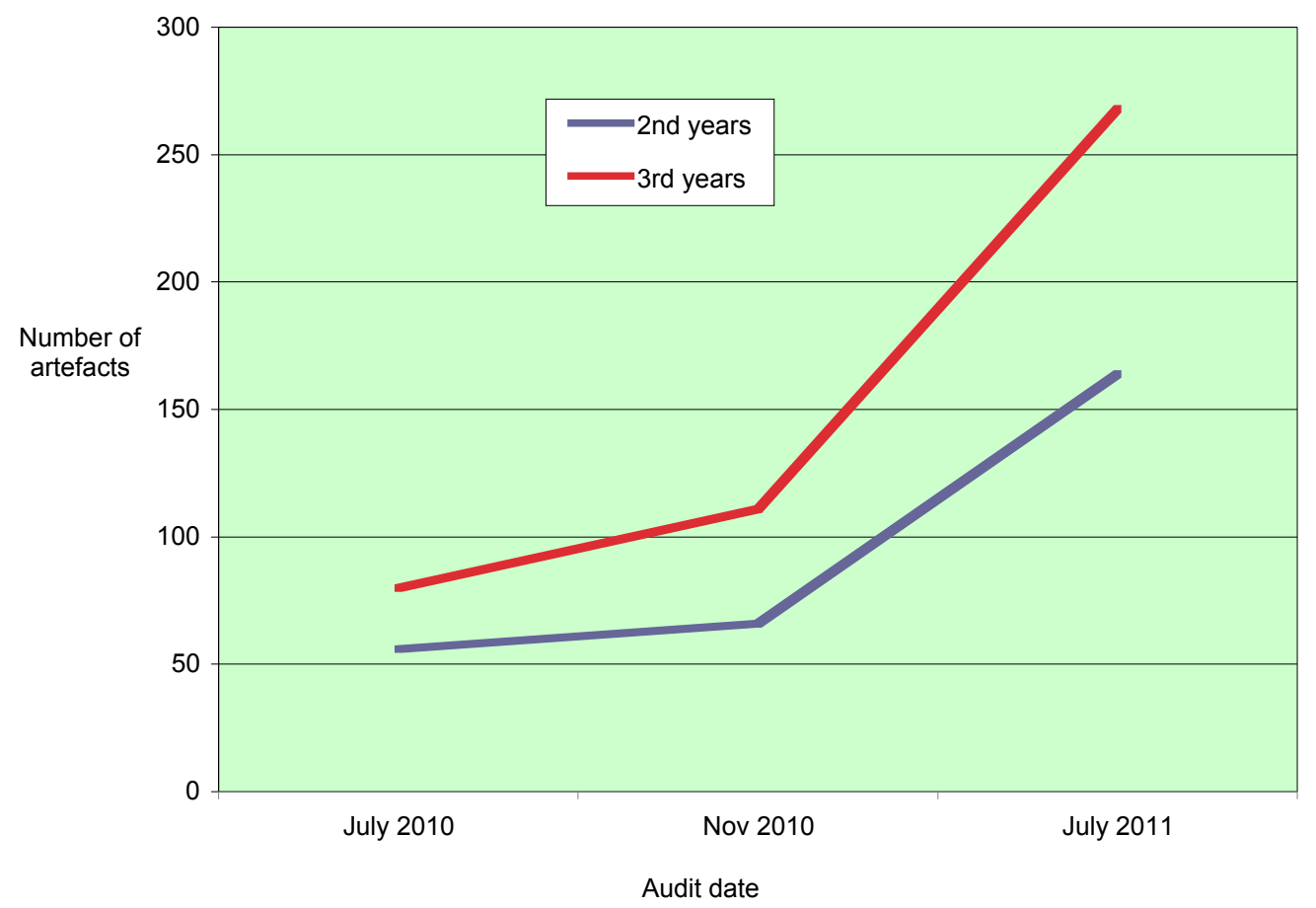

Figure 2: Total number of artefacts created by year group

In order to account for these trends, the artefacts were further sub-divided by gender in each year group, as can be seen in Figure 3. A common trend across both year groups was the greater number of artefacts created by female students compared to their male counterparts. This would suggest that overall, female students' adoption of the e-portfolio was greater than that of the male students. The most important difference in the overall numbers between the year groups at Audit Point 3 is the decrease in artefact numbers by second year, male students from the previous Audit Point.

While the third year, male students' artefact numbers increased, the trajectory of this was significantly more gradual than that of the female students from both year groups, which, surprisingly showed similar relative characteristics between Audit Points 2 and 3.

One possible reason for the higher numbers of artefacts by female students could be due to attendance at training sessions. With one to one sessions available on a firstcome, first-served basis, a significantly higher proportion of female students attended optional training sessions (i.e. a ratio approximately 9:1 in favour of female students). Furthermore, there were many instances of female students attending multiple training sessions, with specific questions regarding artefact creation. The training attendance patterns observed across gender could be one reason for the apparent greater adoption of the e-portfolio by female students, where the training increased confidence in using the platform. Another possible reason could be due to a gender difference in self-perceived technological competence, particularly in relation to the 
perceived technical difficulty in both using the offered e-portfolio platform, and in creating an independent alternative to an e-portfolio (i.e. a student's own website). A further reason could be related to gender differences in attitude towards the course, particularly with regard to the assessment task requirement, with the female students 'taking the e-portfolios more seriously' than the male students. This could be a result of third year students being further advanced in their degree, particularly with regard to having more practice teaching experience, and therefore more understanding of the overall purposes of the degree.

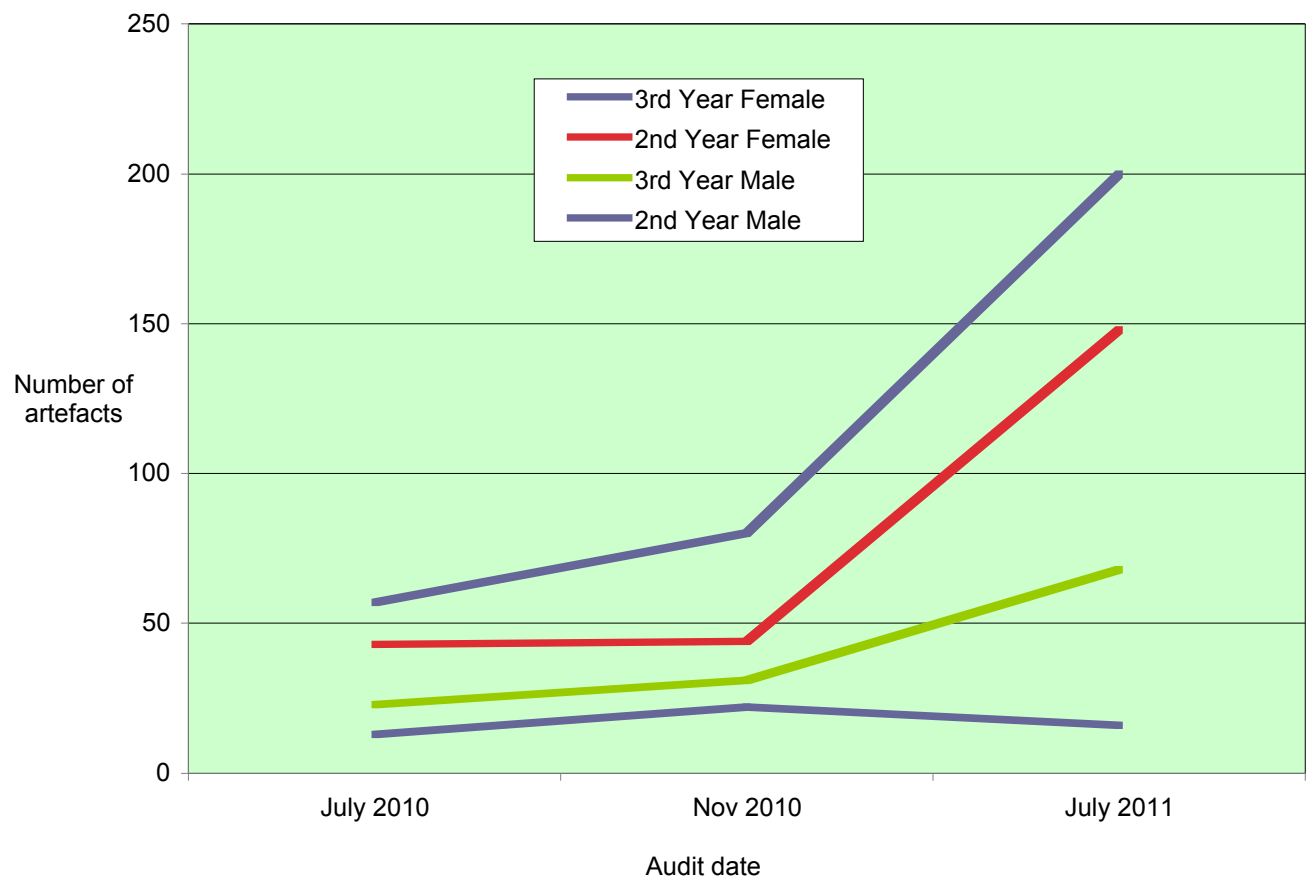

Figure 3: Total number of artefacts created by gender/year group

\section{Gender and year group (educational maturity) differences in artefact creation}

In order to further discuss these hypotheses, it is necessary to refer back to the E-portfolio Component Complexity Framework (ECCF), and apply this typology to all artefacts at each Audit Point. Figure 4 shows the percentage distribution of ranked artefact (according to the ECCF) by gender of the second year students. This data has been adjusted to account for student numbers, thus representing the relative proportions of students who created that artefact type.

The overall complexity of the artefacts created by second year students at Audit Point 1 was low, consisting only of Type 1 and Type 2 artefacts (for example, filling in an online form, or uploading an MS Office-based document). With a fairly even split in percentages in Type 1 artefacts, male students accounted for a greater percentage of the creation of Type 2 artefacts. By Audit Point 2 (as represented by Figure 5) the percentage split of Type 1 artefacts remained the same, although there had been an increase in the number of Type 2 artefacts by female students, making both Type 1 and Type 2 assets relatively even among gender. The biggest change in the second audit 
was the appearance of Type 4 artefacts, particularly given the absence of anything categorised as Type 3. More importantly, only male students had created Type 4 artefacts; this suggests that although the overall artefact numbers presented in Figures 3 and 4 indicate that female students were creating the greater number of artefacts, the actual distribution of artefact complexity was greater and this complexity was implemented sooner with the male students than with the female students.

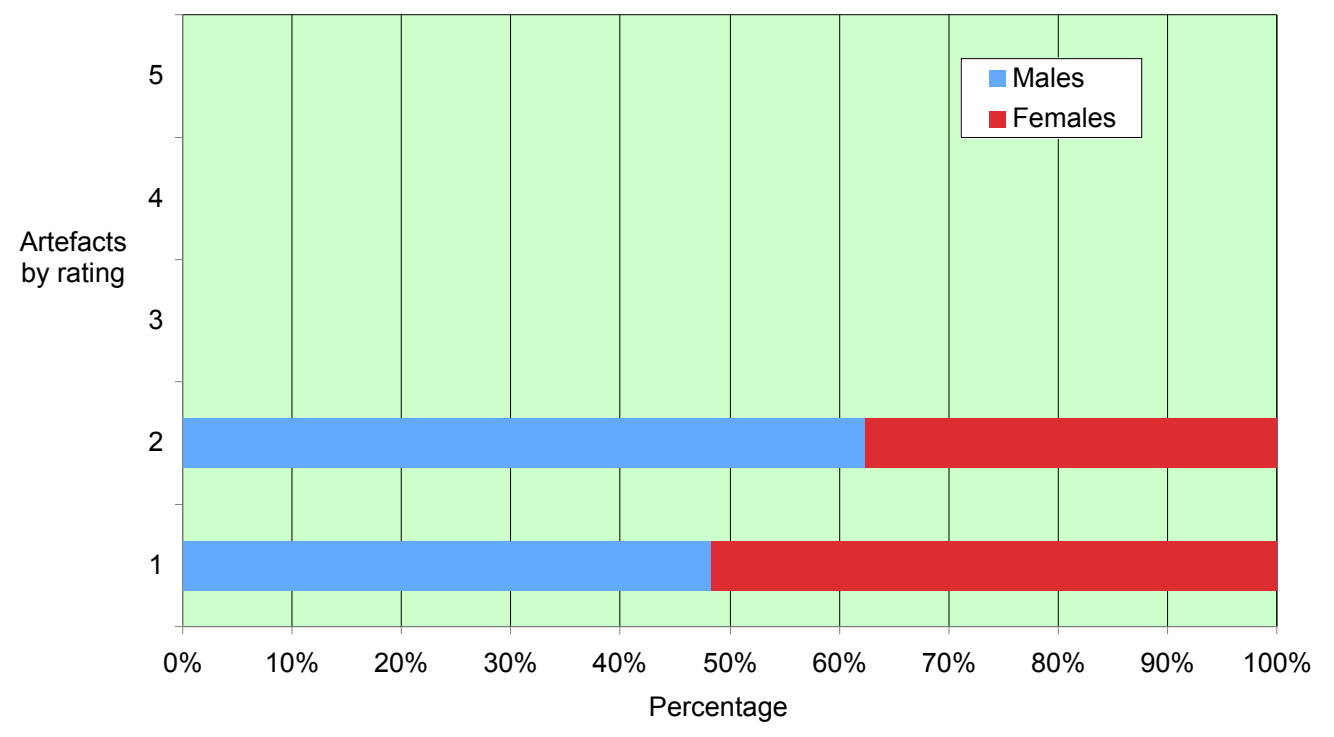

Figure 4: Percentage split of ranked artefacts by gender at Audit Point 1 (second year students)

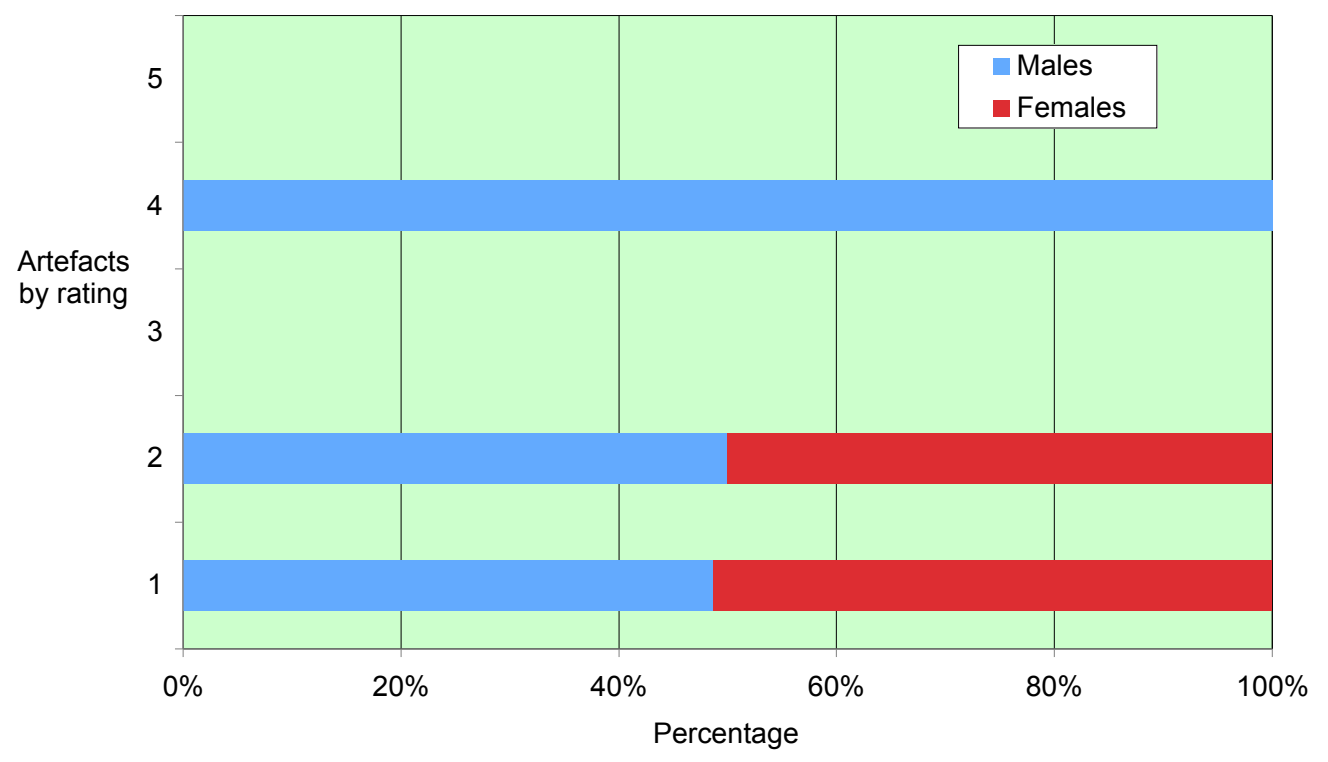

Figure 5: Percentage split of ranked artefacts by gender at Audit Point 2 (second year students) 
By Audit Point 3 (Figure 6) there were artefacts in each of the five ECCF types, although there were dramatic differences in distribution from the previous audit. First, the male students appeared to have created more Type 1 and Type 2 artefacts, as can be seen with the increase in percentages over the female students. Conversely, male students accounted for less than $20 \%$ of the total Type 4 artefacts that had previously seen a $100 \%$ attribution in Audit Point 2. Furthermore, none of the male students had created either Type 3 or Type 5 artefacts, with the female students accounting for these totals.

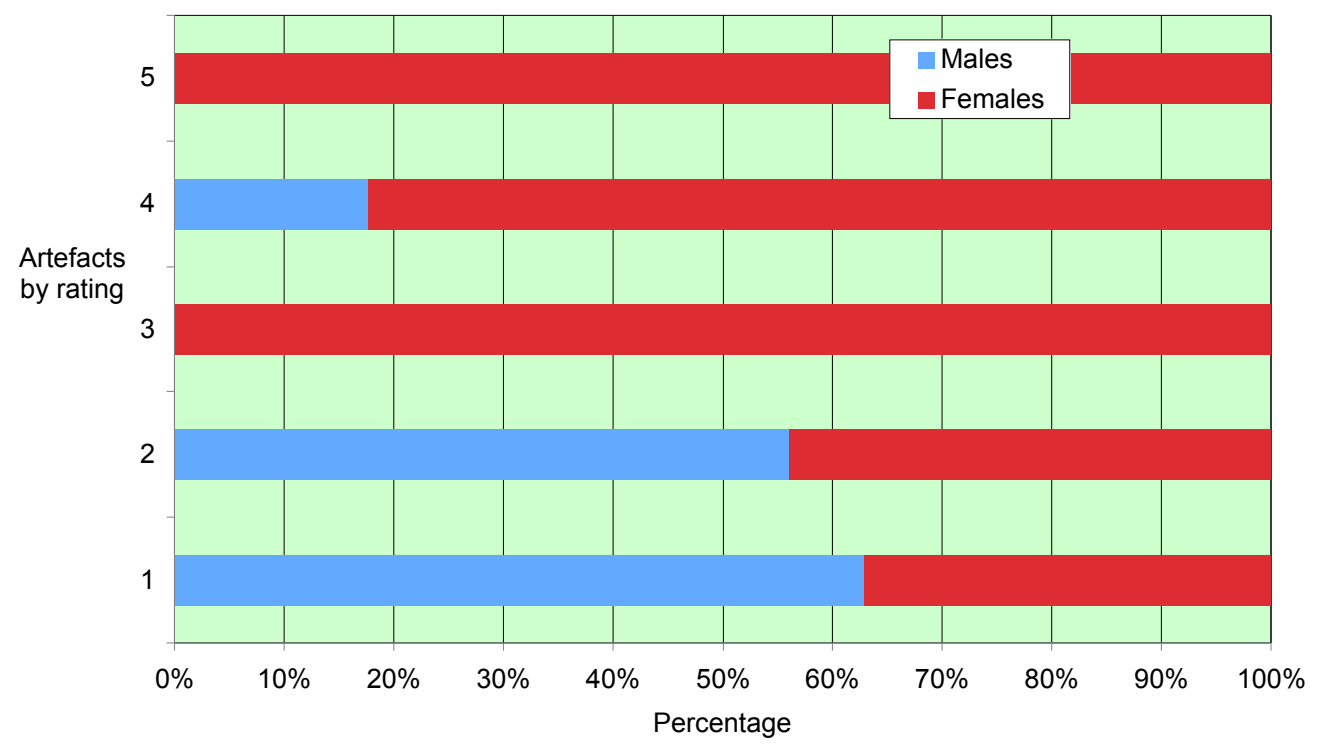

Figure 6: Percentage split of ranked artefacts by gender at Audit Point 3 (second year students)

Had the males' percentages of Type 1 and Type 2 artefacts decreased in the same way as Type 4 artefacts, it could be suggestive of a declining adoption rate. However, the increase in lower complexity items suggests that the male students were not boycotting the e-portfolio; instead it would suggest that they were either not fully realising the technical potential of the e-portfolio platform, or they were not able to fully conceptualise an e-portfolio with a diversity of different artefact types which, in contrast, the female students appeared to be developing. This could further support the argument that this is a result of not attending training where, along with the technical aspects of the e-portfolio platform, a 'vision' of what an e-portfolio should look like (using exemplary portfolios) was also given to help both conceptualisation and contextualisation of the e-portfolio for various educational, personal development and professional functions.

It was noted that at Audit Point 1, the second year, male students had created marginally less Type 1 artefacts than the female students, but more Type 2 artefacts (shown in Figure 4). By comparison, Figure 7 shows how the third year students at the same Audit Point followed a similar trend, with a notable exception that instead of just over $60 \%$ male dominance in Type 2 artefacts, the third year, male students account for about $80 \%$ of this artefact Type. Given that the total number of artefacts created by the 
female students was considerably higher than the male students, it appears that female students were creating more basic artefact types.

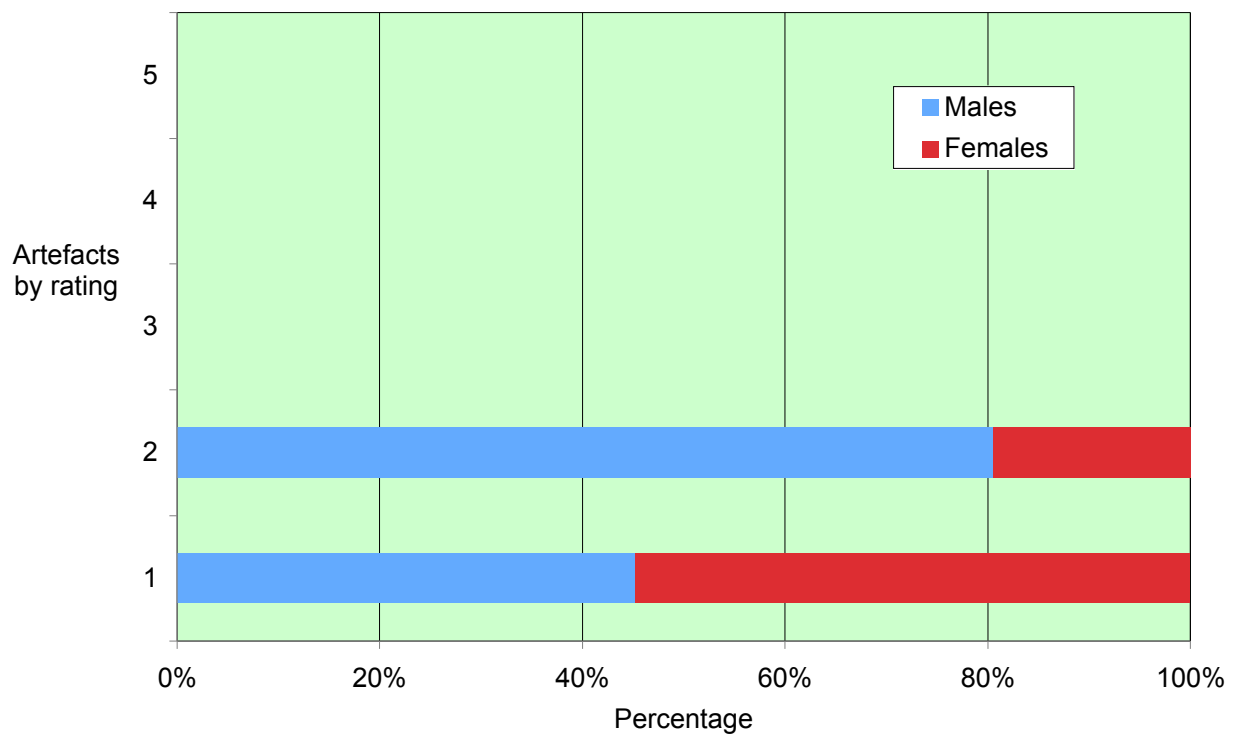

Figure 7: Percentage split of ranked artefacts by gender at Audit Point 1 (third year students)

There could be two reasons for this: either the male students were more confident in using externally generated evidence and uploading it onto their e-portfolios or, they saw the uploading of existing evidence to their e-portfolios as part of an assessment task, as a more practical and easier approach than the potential engagement required with the e-portfolio platform to learn and create Type 1 artefacts.

At Audit Point 2 (shown in Figure 8), the relative attribution of artefact Types 1 and 2 remained similar, although there were Type 3 and Type 4 artefacts to be seen by this Audit Point. With no male students creating Type 3 artefacts, just under $35 \%$ of male students had created Type 4 artefacts. There is a considerable difference between the third year students and second year students at Audit Point 2 regarding Type 3 and 4 artefacts, with second year students failing to create any Type 3 artefacts, and the male students creating $100 \%$ of the Type 4 artefacts. This suggests that the third year, female students were contextualising their e-portfolios far more than the second year, female students and, in turn, the third year, male students.

Audit Point 3 for third year students (Figure 9) saw the creation of all artefact types although, in comparison to the second year group, the male students were significantly more active (particularly in Types 3 and 4) than the female students, who accounted generally for more artefacts than the male students. Similarly, neither second nor third year, male students created any Type 5 artefacts, with this Type being dominated by female students.

By Audit Point 3, an interesting contrast in Type 1 and Type 2 artefacts had occurred, whereby Audit Points 1 and 2 saw a male student majority of Type 2 assets decline to a minority and, conversely, a minority of Type 1 artefacts became a majority. This 
increase in Type 1 artefacts is consistent with the increase in Type 3 and 4 artefacts, and suggests that the male students had become more active in their e-portfolio usage. A further observation relates to the increased creation of Type 2 artefacts in third year, female students, compared to the second year equivalents, with this artefact Type seeing the only female student increase.

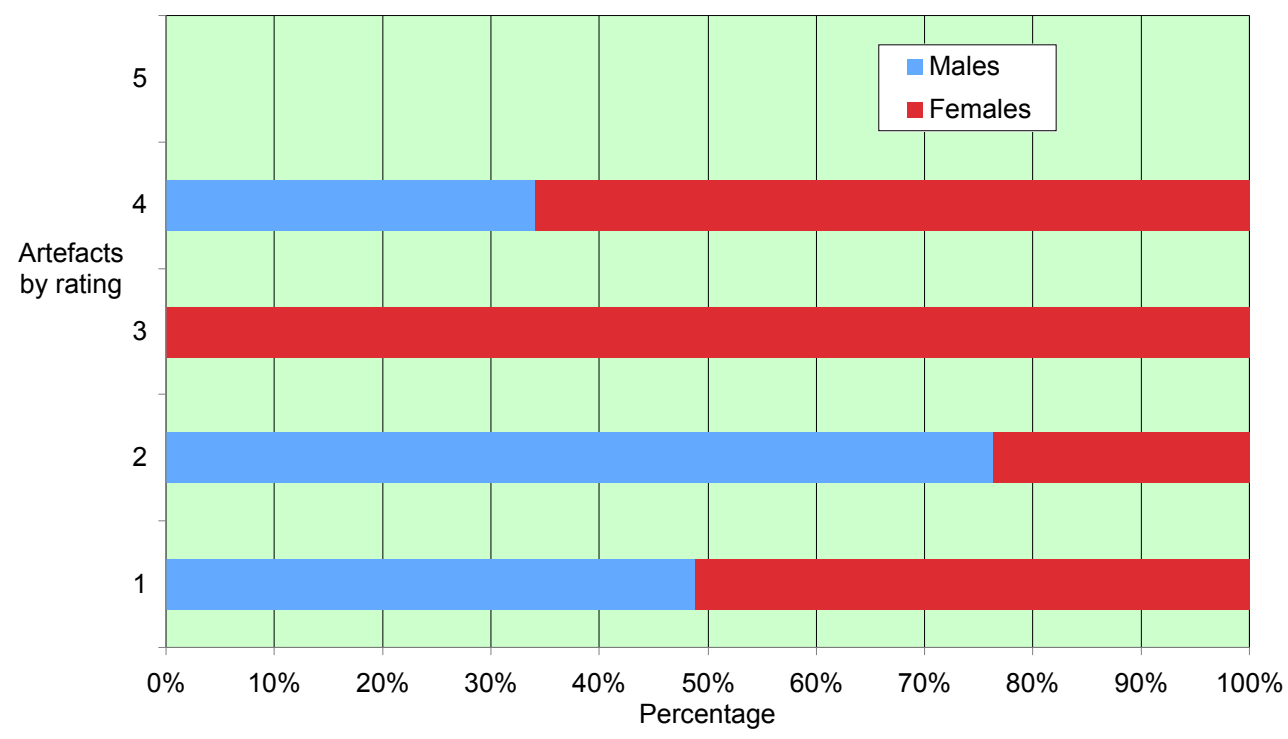

Figure 8: Percentage split of ranked artefacts by gender at Audit Point 2 (third year students)

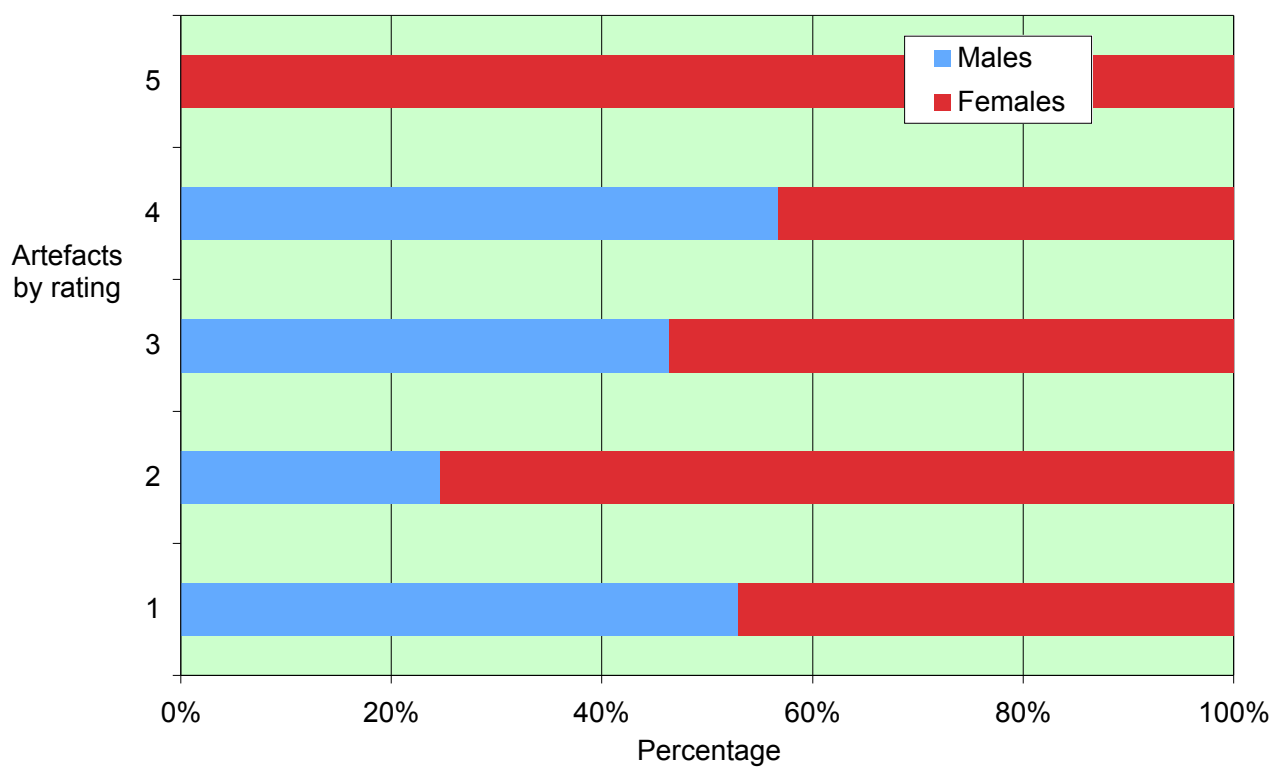

Figure 9: Percentage split of ranked artefacts by gender at Audit Point 3 (third year students) 
Overall, the third year students, even though they were at a more advanced stage of the degree than the second year students, were slower to adopt e-portfolios than the second year students, but once adopted, male students accounted for a greater percentage of the artefacts, although female student adoption was much greater in general. Furthermore, the third year, male students were much more conceptual in their application of artefacts than the second year students, with a higher proportion of Type 4 artefacts. One explanation for the differences in artefacts between the year groups could be attributed to the timing of Prac, where Audit Point 2 occurred during the second year students' Practice Teaching session and, by which point, the third year students had already completed Prac for that semester.

Having discussed the differences in artefact type creation across year group and gender, it is necessary to further investigate the relative distribution trajectories of each type over the three Audit Points, with a particular aim of identifying these distribution paths.

\section{E-portfolio construction and artefact distribution}

In order to construct an e-portfolio, a student must create what could be deemed 'base class' artefacts, which have little or no abstraction in the typology presented in this article (i.e. factual information). These artefacts are necessary for the construction of an e-portfolio, and are quite often integrated into the platform by way of online forms, which collect basic information about a student such as name and contact information, etc. The data presented thus far, suggests that the early stages of e-portfolio creation require a higher proportion of base class artefacts in order to construct a general framework for the e-portfolio. Furthermore, once the e-portfolio framework has been established, students begin creating artefacts that provide detail to the framework, consisting of more evidentiary material of differing complexity, ranging from the more common (and lower complexity) text documents (Type 2) to more complex (and less common) video documents, each containing inherent (and markedly different) technological difficulties. It is expected that the maturation of an e-portfolio framework will produce a level distribution curve of artefacts.

Having discussed the relative gender distribution of artefact creation across the three Audit Points, it is important to examine the distribution of these artefact types within each year group as a total percentage of artefacts created, in order to determine the overall contribution of each artefact type, and the trajectory of artefact creation across the three audit points.

Figure 10 shows the artefact distribution of the second year students by Audit Point. Despite similarities between Audit Points 1 and 2, the distribution of artefact types by Audit 3 becomes more even, with Types 1 and 4 being most dominant.

Furthermore, Type 3 artefacts (i.e. online referencing) and Type 5 artefacts (i.e. video) are significantly lower than expected. Increases in Type 4 artefacts show greater confidence in e-portfolio usage, with this confidence manifesting itself in an increase in the conceptual integration of assets, where students focus their attention on creating more complex digital artefacts. More significantly, Fig 11 shows artefact distribution of third year students by Audit Point, where the distribution changes are more gradual across the Audit Points. 


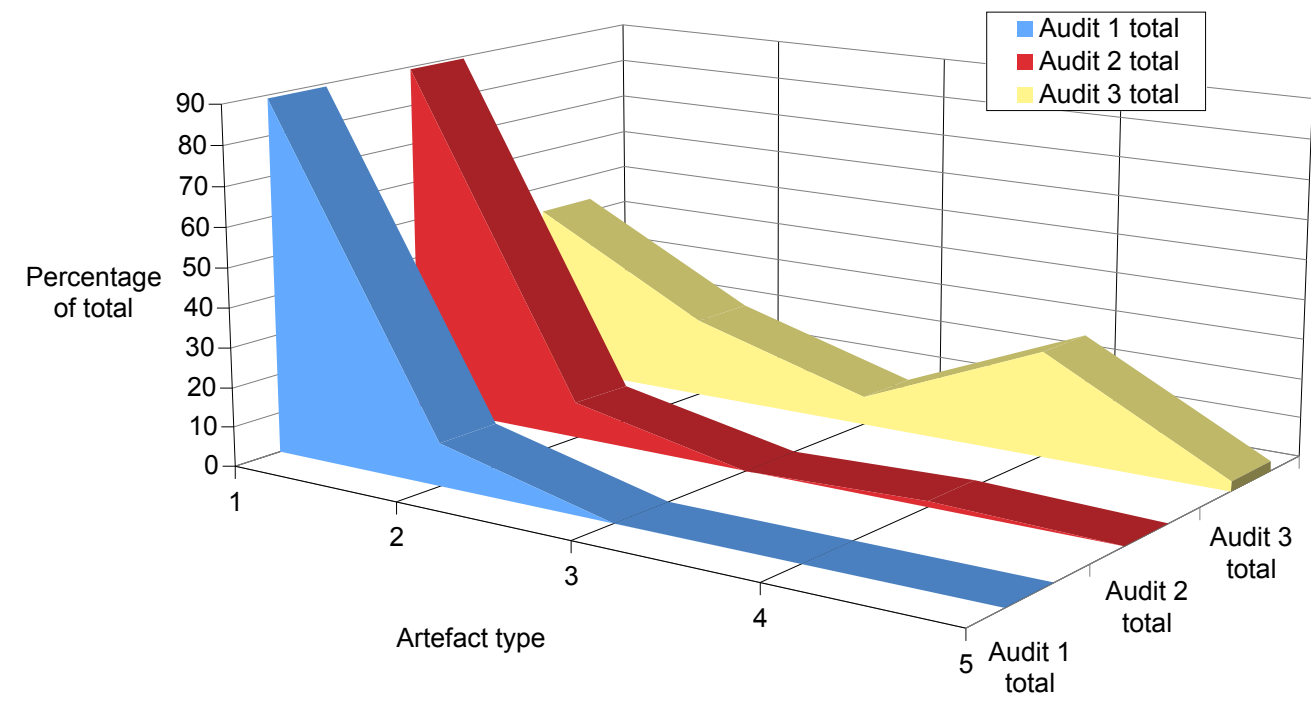

Figure 10: Comparison of artefact ranking distribution of second year students

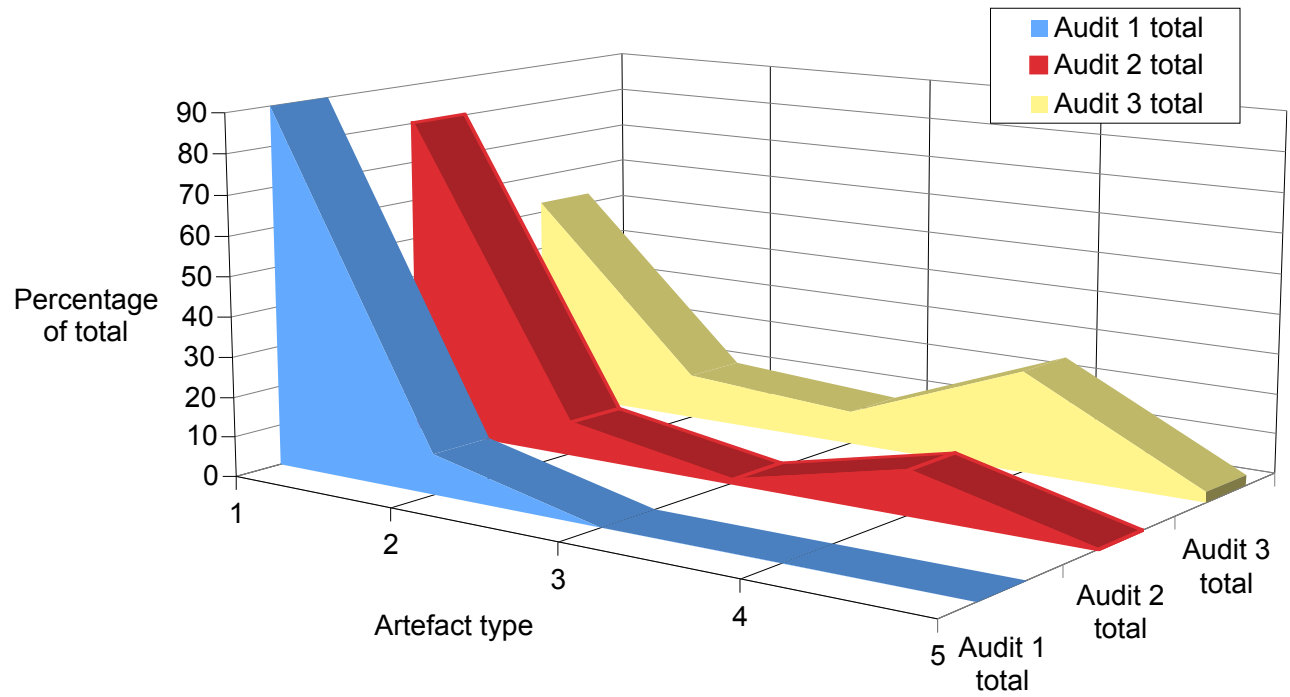

Figure 11: Comparison of artefact ranking distribution of third year students

Interestingly, the distribution follows a similar trend to the second year students, where more Type 1 artefacts are created to begin with, followed by an increase in contextual thinking with a greater spread of artefact types. This suggests that as students develop their e-portfolios, the first stage of the process is to create simple artefacts, shifting to a more contextual type of thinking in asset linkage to create integrated, balanced representations of evidence, knowledge and self awareness. However, the extent to which the type distribution can occur may depend on several factors, including e-portfolio parameters, assessment tasks, student experience, technological friction, network partitioning, and student perception of artefact use. 


\section{E-portfolio parameters}

The first of these factors that is important to the overall level of Type 1 artefacts, relates to base class artefacts and their constituent make-up within e-portfolio platforms.

Where an e-portfolio platform requires a significant number of Type 1 artefacts to develop the e-portfolio framework, (i.e. information-based pages, etc.), the relative distribution of artefacts may become distorted, inhibiting contextual e-portfolio thinking, as the initial focus of the e-portfolio work elongates the creation of Type 1 artefacts over the e-portfolio process.

\section{Assessment tasks}

Assessment tasks may also affect the created artefact types, where assessment may focus on Type 1 artefacts during the initial phases of the e-portfolio implementation. A student's unfamiliarity with the e-portfolio platform, combined with different levels of technological experience, makes training in the initial introduction of e-portfolios very important. Without a clear understanding of base class artefacts and the interdependence of elements of the platform framework, an e-portfolio growth is stunted and is unlikely to be utilised to its full potential. In addition, limited student experience makes it more difficult to associate e-portfolios with purpose of the degree. Therefore, it is important that training support also encompass some 'visionary selling' to overcome this. Audit data that supports platform unfamiliarity, and technological and educational experience, can be seen with the second year male students in Figure 3, whose artefact creation by Audit Point had decreased.

\section{Training}

Training given to the students (and their subsequent take up of this training), could also account for an increase in artefact types. Additionally, students' varied technological skill levels contributed to the type of advice and training given, with lower technological skill levels requiring instruction on less complex artefact types, and higher technological skills requiring instruction on more complex artefact types. Furthermore, it was noted during the training sessions that some students would use the training to complete specific assessment tasks, rather than learn the generic processes required for e-portfolio construction.

\section{Student experience}

Previous discussion has described how third year students created more artefacts in general than the second year students, and is indicative of another factor - student experience. It was hypothesised in an earlier section of this discussion that the additional year of study gained by the third year of the degree, (which in this context also includes additional Practice Teaching time, and other co-curricular experiences, such as international field work) had a significant impact on students' understanding of the purpose of the degree. Moreover, additional experiences and practice teaching time allowed students to encounter teaching situations that led to more technologically complex artefact production. For example, the filming of rehearsals, classroom teaching, working with musicians internationally, and community engagement.

This understanding has a positive impact on students' contextualisation of e-portfolios, where students recognise the use of demonstrative materials capable of presenting 
their skills and knowledge gained throughout their study. Student experience is affected by assessment tasks that fit with the experience that the student wishes to demonstrate, for example, a student could be constrained in demonstration of a key skill if an assessment task does not allow for this artefact type (e.g. creation of a textbased document when a video could be more appropriate). The experience of the student may be higher than their level of technological skill, requiring appropriate training to implement the demonstration through the correct artefact type.

\section{Technological friction}

Student adoption of the e-portfolio platform is dependant on the e-portfolio environment and its technical manifestation. Where the technological skill level and experience of the student is commensurate with the methodologies employed to create artefacts, a synergy exists; where they are not, a 'technological friction' exists, in which either a student is technologically experienced, and the e-portfolio platform is considered inadequate or not user friendly (informal friction), or where the student is technologically inexperienced and considers the e-portfolio platform to be too challenging (formal friction). Although both friction types inhibit e-portfolio adoption and usage, a student experiencing informal friction may require teachers to compensate for this by increasing the technological difficulty of assessment tasks, and by appealing to the students experience levels in the demonstration of study skills. For a student experiencing formal friction, it is necessary to provide access to e-portfolio training that will assist in building a confidence with the e-portfolio platform, from base class artefacts through to more advanced artefact types.

\section{Network partitioning}

It is quite likely that the contemporary student will be a member of one or more social media or online networking sites, and that they are likely to have an established 'digital footprint' (Gray et al, 2010). This raises important issues relating to students' perceptions of private and professional online networks. Given the networking and professional development possibilities of e-portfolios, there appears to be relatively little integration of social media and online networking sites within e-portfolios, as indicated by the limited number of Type 3 artefacts created by all students audited in this project. This lack of integration, or network partitioning, is an interesting area of student e-portfolio behaviour presented in this study. Factors that affect the level of network partitioning include the students' perception of the e-portfolio as something that is both integrative and useful for professional development.

Where student experience is high, an e-portfolio may be considered a viable alternative to other online professional development networks. Conversely, the same student may wish to partition their personal online social networks from their eportfolio, as these are deemed unsuitable for professional development. Furthermore, low student experience might lead to seeing an e-portfolio only as an alternative to existing social media networks, consequently partitioning it from existing networks due to its affiliation with their studies.

It is also worth noting that many of the online social networks have become entrenched in technology, insofar as there are dedicated buttons on some smartphones, which automatically connect the user to their network. Such networking habits may be difficult to break, and the perception of another university-related site might not appear culturally popular or appropriate. 


\section{Perception of high type artefact use}

With the common use of video-sharing websites, such as YouTube and Vimeo, and uploading video files to existing online social networks, one question arises when considering the overall lack of progressive use of Type 5 artefacts, such as video: how many students are likely to have created videos and uploaded them to videosharing/online networking sites, that are not utilising this technological aspect of the e-portfolio capability? This may be due to e-portfolio platform constraints, where maximum upload limits exist which constrain video size and/or quality.

The integration of video-sharing networks within smartphones provides the capability and ease in which a user can create a video and upload it instantly, with very few technical constraints (i.e. the video taken on the smartphone will be automatically encoded in the correct format, with little constraint on size). The need to upload video to a personal network space (whether onto an online social network or an e-portfolio) on an ad-hoc basis suggests two different approaches to the creation of a video artefact. With an ad-hoc video taken on a smartphone being perceived as unsuitable for professional contexts, the abstraction and planned methodology in the creation of Type 5 artefacts would correspond to a high level of student experience combined with sufficient training.

\section{Conclusion}

The results of the analysis of students' e-portfolios discussed in this article, provide insights into the complexities of e-portfolio adoption and usage in an educational setting, and identify the interaction and co-dependency of student and technological parameters inherent in online, real and educational worlds. Our audits of student eportfolio work reinforce the opinion of various writers in the area of educational technology, that uses of forms of online infrastructure in teaching and learning are complex, and not one-dimensional or straightforward (e.g. Joyes, 2010; Gray et al, 2010).

Our analyses of student e-portfolios demonstrate how numerous student-based variables influence the design and content of e-portfolios and how users relate to them. Gender, degree program cohort, technological acumen, levels of training, artefact typology, and acceptance of online self-representation, were all issues that were revealed as the project unfolded.

A second set of variables adds to the potential complexity of e-portfolio use. These relate to institutional expectations of their introduction and application, and their roles in the delivery of teaching and the assessment of student learning. A third and less clearly defined factor, is that of students' digital identities outside of their studies identities represented and expressed through social networking sites, blogs, personal and group websites, etc. In some ways these can be defined as a form of 'prior learning' for e-portfolio use. While our use of e-portfolios relates to undergraduate training in music education, the issues discussed here, and the three sets of factors outlined, are not discipline specific; the music and music education-related aspects of e-portfolios were not problematic for students. This leads us to surmise that at least two levels of e-portfolio exist: a discipline specific one, and a generic one.

Analysis of our students' e-portfolios as generic indicators of their use leads us to pose suggestions for other institutions. Our typology of artefacts shows the importance of 
ensuring that the platform being used has a well-balanced framework typology, without a large amount of base class artefacts. e-portfolios should allow a student to develop skills in other technological spheres, without being bound to low type artefact creation in order to demonstrate higher artefact types. One of the most challenging parameters of e-portfolio usage relates to the role of the e-portfolio within the online and real worlds. As an intermediary of education and career development within an online, networking paradigm, it is important to ensure that students are fully aware of the role of an e-portfolio, and its application both from an online, networking perspective, and from a real world, career development one. A model showing the intermediary nature of the e-portfolio between educational and career development and, personal and professional digital footprint applications can be seen in Figure 12.

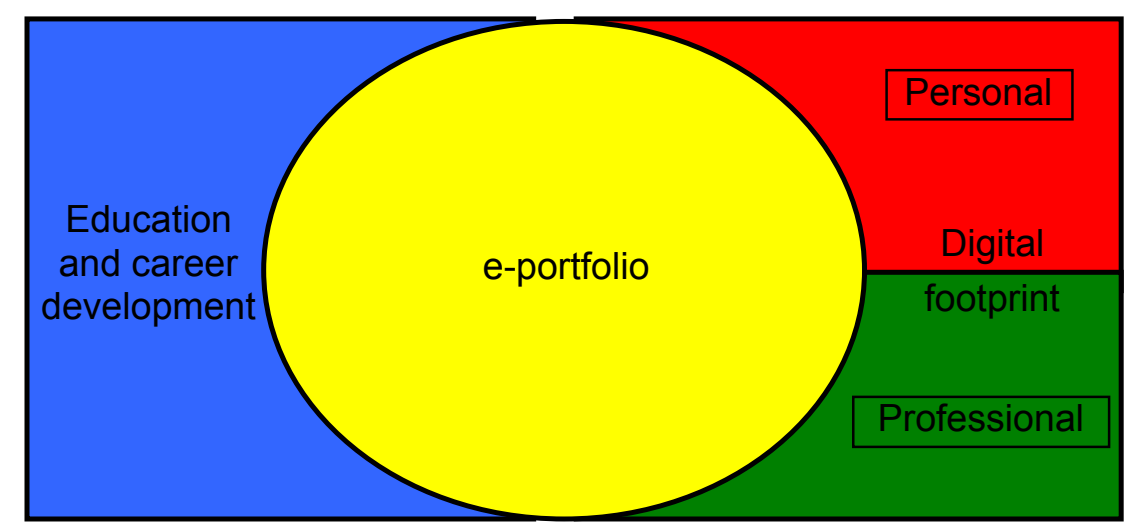

Figure 12: The e-portfolio as intermediary in the real world and online networking paradigm

Clear understanding of the different applications of each networked medium can avoid network partitioning, and allow students to maximise their network potential within educational and career development. Technologically, the e-portfolio platform must also have the capability to easily integrate existing digital footprints, with the possibility to share artefacts between networks.

Once an understanding of the roles and integrative networking potential of the eportfolio have been realised, it is important that e-portfolios are strategically implemented within the curriculum, with particular reference to artefact typology. By moving from lower artefact types to higher artefact types, students inherently have greater opportunity to develop a wide range of technology-oriented skills. This could assist in increasing levels of student experience as they attempt to contextualise activities within an educational and career development perspective.

One of the key challenges of e-portfolio implementation is to ensure that there is awareness and balance between all of the parameters described in this discussion, and that these are maintained within assessment strategies. In considering these interrelationships, a model is presented in Figure 13, which highlights zones of balance and complexity that are a result of tensions between parameters extrapolated from our audits: platform framework typology, student experience, technological skills, assessment tasks, and training needs. 


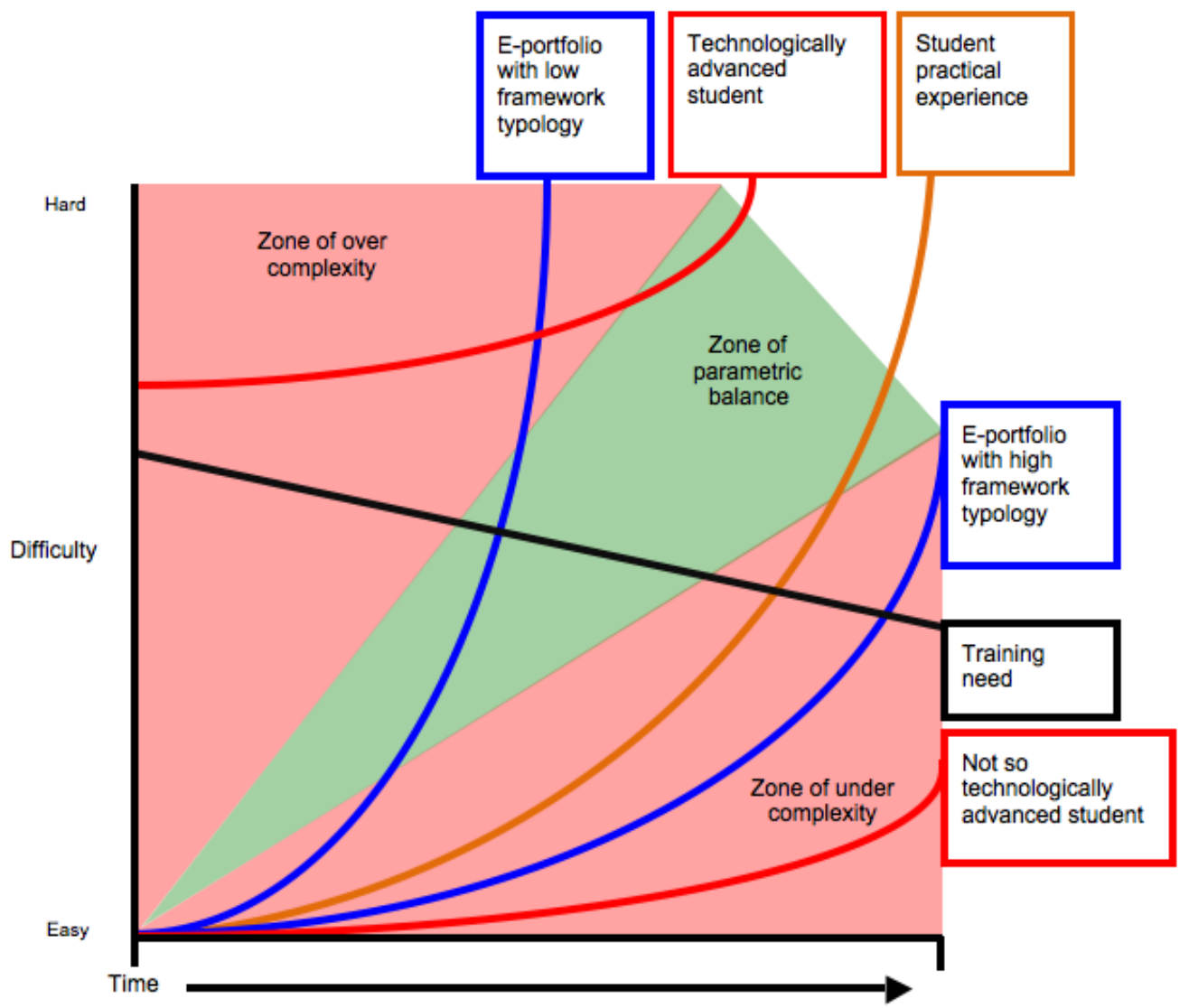

Figure 13: The zone of parametric balance between student, technology and assessment

This model presents an ideal zone of parametric balance, with the aim of describing assessment difficulty in relation to different student skills and experience, and technological considerations with different framework typologies, in order to mitigate the effects of technological friction. It is acknowledged that the fluidity of the zone of parametric balance may differ not only between educational contexts, but also between students. With the parametric balance supported by adequate training provision, teachers can maximise adoption of e-portfolios and minimise future training needs, while also providing a balanced technological skillset to the student that can be utilised in career development.

\section{References}

Akcil, U. \& Arap, I. (2009). The opinions of education faculty students on learning processes involving e-portfolios. Procedia Social and Behavioral Sciences, 1, 395-400. http: / / dx.doi.org/10.1016/j.sbspro.2009.01.071

Barrett, H. (2001). ICT support for electronic portfolios and alternative assessment. Proceedings of the 2001 World Conference for Computers in Education: Networking the Learner, 569-578.

http: / / dl.acm.org/ citation.cfm?id=756674 [also at

http:/ / electronicportfolios.com/portfolios/wcce2001.pdf] 
Barrett, H. \& Garrett, N. (2009). Online personal learning environments: Structuring electronic portfolios for lifelong and life-wide learning. On The Horizon, 17(2), 142-152. http: / / dx.doi.org/10.1108/10748120910965511

Botterill, M., White, C. \& Steiner, T., (2010). Developing professional skills: Introducing students to graduate attributes in first year engineering at RMIT. Proceedings of ePortfolios Australia Conference 2010, 15-26. http:/ / eportfoliosaustralia.files.wordpress.com/2012/05/ eac2010 _abstracts_ebook_20101214.pdf

Challis, D. (2005). Towards the mature ePortfolio: Some implications for higher education. Canadian Journal of Learning and Technology, 31(3). http:/ / www.cjlt.ca/index.php/cjlt/ article/ view / 93/87

Chau, J. \& Cheng, G. (2010). Towards understanding the potential of e-portfolios for independent learning: A qualitative study. Australasian Journal of Educational Technology, 26(7), 932-950. http:/ / www.ascilite.org.au/ ajet/ ajet26/ chau.html

Darnton, R. (2011). Five myths about the 'information age.' The Chronicle of Higher Education. http:/ / chronicle.com/article/5-Myths-About-the-Information/127105/ [viewed 13 July 2011]

Dunbar-Hall, P., Rowley, J., Webb, M. \& Bell, M. (2010). ePortfolios for music educators: Parameters, problems and possibilities. Proceedings of the 29th Conference of the International Society for Music Education, Beijing, 61-64. [verified 19 Oct 2012] http: / / issuu.com/official_isme/docs/isme29/search?q=rowley

Garrett, B. \& Jackson, C. (2006). A mobile clinical e-portfolio for nursing and medical students: Using wireless personal digital assistants. Nurse Education in Practice, 6(6), 339-346. http: / / dx.doi.org/10.1016/j.nepr.2006.07.015

Granberg, C. (2010). E-portfolios in teacher education 2002-2009: The social construction of discourse, design and dissemination. European Journal of Teacher Education, 33(3), 309-322. http: / / dx.doi.org/10.1080/02619761003767882

Gray, K., Thompson, C., Sheard, J., Clerehan, R. \& Hamilton, M. (2010). Students as Web 2.0 authors: Implications for assessment design and conduct. Australasian Journal of Educational Technology, 26(1), 105-122. http:/ / www.ascilite.org.au/ajet/ajet26/gray.html

Hemmi, A., Bayne, S. \& Land, R. (2009). The appropriation and repurposing of social technologies in higher education. Journal of Computer Assisted Learning, 25(1), 19-30. http:/ / dx.doi.org/10.1111/j.1365-2729.2008.00306.x [also at http: / / www.malts.ed.ac.uk/staff/sian/pdfs/jcal_paper.pdf]

Jones, A., Barnes, P., Lindley, D., Steinberg, A., Upadhyay, V. \& Wilkinson, K. (2010). The role of ePortfolios in mentoring adult learners seeking professional certification. Proceedings of ePortfolios Australia Conference 2010, 82-89. http:/ / eportfoliosaustralia.files.wordpress.com/2012/05/eac2010_abstracts_ebook_20101214.pdf

Joyes, G., Gray, L. \& Hartnell-Young, E. (2010). Effective practice with e-portfolios: How can the UK experience inform implementation? Australasian Journal of Educational Technology, 26(1), 15-27. http:/ / www.ascilite.org.au/ajet/ajet26/joyes.html

Marriott, A. \& Chomba, F. (2010). Seoul Accord iPortfolio template for computing students. Proceedings of ePortfolios Australia Conference 2010, 113-114. http:/ / eportfoliosaustralia.files.wordpress.com/2012/05/eac2010_abstracts_ebook_20101214.pdf

McAlpine, M. (2005). E-portfolios and digital identity: Some issues for discussion. E-learning, 2(4), 378-387. http: / / dx.doi.org/10.2304/elea.2005.2.4.378

Oliver, B. \& Goerke, V. (2007). Australian undergraduates' use and ownership of emerging technologies: Implications and opportunities for creating engaging learning experiences for the Net Generation. Australasian Journal of Educational Technology, 23(2), 171-186. http:// www.ascilite.org.au/ajet/ajet23/oliver.html 
Oliver, B. (2010). ePortfolios, employability and standards: How might emerging ePortfolio systems assist the implementation of national policies of academic standards and key graduate capabilities? Proceedings of ePortfolios Australia Conference 2010, 136-137. http:/ / eportfoliosaustralia.files.wordpress.com/2012/05/eac2010_abstracts_ebook_20101214.pdf

Oliver, B. \& Nikoletatos, P. (2009). Building engaging physical and virtual learning spaces: A case study of a collaborative approach. In Same places, different spaces. Proceedings ascilite Auckland 2009. http: / / www.ascilite.org.au / conferences / auckland09/ procs / oliver.pdf

Oliver, B., von Konsky, B. R., Jones, S., Ferns, S., \& Tucker, B. (2009). Curtin's iPortfolio: facilitating student achievement of graduate attributes within and beyond the formal curriculum. Learning Communities: International Journal of Learning in Social Contexts, 2, 4-15. http: / / www.cdu.edu.au/centres/ spill / / journal/IJLSC_Dec_2009_eportfolio.pdf

Rowley, J. (2010). Technology, innovation and student learning: ePortfolios for music education. In C. Nygaard, N. Courtney \& C. Holtham (Eds.), Beyond transmission: Innovations in university teaching. Faringdon: Libri Publishing.

Rowley, J. L. \& Dunbar-Hall, P. (2009). Integrating e-portfolios: Putting the pedagogy in its place. In Same places, different spaces. Proceedings ascilite Auckland 2009. http: / / www.ascilite.org.au/conferences/auckland09/procs/rowley.pdf

Rowley, J. \& Dunbar-Hall, P. (2010). Integrating e-portfolios for music teachers: A creative and pedagogic undertaking. Proceedings of the Society for Information Technology and Teacher Education International Conference, 213-215. http:/ / www.editlib.org/ p/33337

Rowley, J. \& Dunbar-Hall, P. (2011a). Mapping curriculum for ePortfolio integration into assessment. Paper presented at Making a difference - showing the difference: ePortfolios Conference Australia 2011, Perth, 108-109. http: / / eportfoliosaustralia.files.wordpress.com / 2012/01/eac2011_ebook_v2_20111125.pdf

Rowley, J. \& Dunbar-Hall, P. (2011b). Uncovering the meanings of ePortfolios: Action research, students, and music teacher preparation. Paper presented at the XVIIth National Conference of the Australian Society for Music Education, Gold Coast. http: / / search.informit.com.au / documentSummary;dn=927600503105195;res=IELHSS

Stewart, S. (2010). The challenges of maintaining a professional midwifery ePortfolio in the cloud. Proceedings of ePortfolios Australia Conference 2010, 168-169. http:/ / eportfoliosaustralia.files.wordpress.com/2012/05/eac2010_abstracts_ebook_20101214.pdf

Sutherland, S., Brotchie, J. \& Chesney, S. (2011). Pebblegogy: Ideas and activities to inspire and engage learners. Telford: Pebble Learning.

Von Konsky, B. \& Comfort, J. (2010). The iPortfolio: A tool for work integrated learning for health promotion students. Proceedings of ePortfolios Australia Conference 2010, 185-186. http:/ / eportfoliosaustralia.files.wordpress.com/2012/05/eac2010_abstracts_ebook_20101214.pdf

Widdowson, K. (2010). From pets to Pebblepad - using ePortfolios to assess workplace learning in veterinary nursing. Proceedings of ePortfolios Australia Conference 2010, 187. http:/ / eportfoliosaustralia.files.wordpress.com/2012/05/eac2010_abstracts_ebook_20101214.pdf

Authors: Mr John Taylor, PhD Researcher

Dr Peter Dunbar-Hall, Honorary Associate Professor

Dr Jennifer L. Rowley, Lecturer in Music Education

Sydney Conservatorium of Music, The University of Sydney, NSW 2006 Australia

Email: john.taylor@sydney.edu.au, peter.dunbar-hall@sydney.edu.au,

jennifer.rowley@sydney.edu.au Web: http: / / sydney.edu.au/music/

Please cite as: Taylor, J., Dunbar-Hall, P. \& Rowley, J. (2012). The e-portfolio continuum: Discovering variables for e-portfolio adoption within music education. Australasian Journal of Educational Technology, 28(8), 1362-1381.

http: / / www.ascilite.org.au/ajet/ajet28/taylor.html 